\title{
EFFECTS OF CYTOKININS ON in vitro MINERAL ACCUMULATION AND BUD DEVELOPMENT IN Annona glabra L.
}

\author{
Efeito de citocininas sobre o acúmulo de minerais e desenvolvimento \\ de brotações de Annona glabra L. in vitro \\ Lenaldo Muniz de Oliveira ${ }^{1}$, Renato Paiva ${ }^{2}$, José Raniere Ferreira de Santana ${ }^{3}$, \\ Flávia Dionísio Pereira ${ }^{3}$, Raírys Cravo Nogueira ${ }^{2}$, Luciano Coutinho Silva $^{2}$
}

\begin{abstract}
Annona glabra is a tropical species that has significant agronomic potential in terms of furnishing fruits for in natura consumption and for the production of phyto-pharmaceuticals. In vitro cultivation has been considered the most promising form of propagation for this species, although large scale utilization of this technique is currently limited by high rates of leaf abscission, reduced rates of explant multiplication and slow bud growth. The present work evaluated the effects of different cytokinins on mineral accumulation in shoots of $A$. glabra cultivated in vitro, and their effects on growth and survival of these plants. Buds of $A$. glabra were cultivated in Wood Plant Medium (WPM) in the presence of 6-benzilaminopurine (BAP), thidiazuron (TDZ), kinetin (KIN), and zeatin (ZEA). KIN and BAP use resulted in the greatest growth, largest accumulation of dry mass and leaf area development, as well as the greatest survival rate during in vitro cultivation of this species. All cytokinins tested stimulated large accumulations of nitrogen and boron in shoots, but diminished levels of calcium as compared to controls.
\end{abstract}

Index terms: Growth regulators, Annonaceae, mineral nutrition.

\section{RESUMO}

Annona glabra é uma espécie frutífera tropical que apresenta elevado potencial agronômico pelo fornecimento de frutos para o consumo in natura e pela produção de fitofármacos. O cultivo in vitro tem sido preconizado como a forma mais adequada de propagação para essa espécie, embora sua utilização em larga escala ainda seja limitada pela elevada taxa de abscisão foliar, reduzida taxa de multiplicação dos explantes e crescimento lento das brotações. Objetivou-se, neste trabalho, avaliar o efeito de citocininas sobre o acúmulo de minerais nas brotações de $A$. glabra cultivadas in vitro e seus reflexos sobre o crescimento e sobrevivência das plantas nesse tipo de ambiente. Brotações de A. glabra foram cultivadas em meio Wood Plant Medium (WPM), na presença de 6benzilaminopurina (BAP), thidiazuron (TDZ), cinetina (KIN) e zeatina (ZEA). A utilização de KIN e BAP induziu maior crescimento, maior acúmulo de massa seca, maior desenvolvimento da área foliar e maior taxa de sobrevivência das plantas durante o cultivo in vitro dessa espécie. Todas as fontes de citocininas testadas estimularam maiores acúmulos de nitrogênio e boro nas brotações e menores de cálcio.

Termos para indexação: Reguladores de crescimento, Annonaceae, nutrição mineral.

(Received in june 18, 2009 and approved in march 17, 2010)

\section{INTRODUCTION}

Annona glabra is a tropical species belonging to the family Annonaceae. It produces flavorful fruits that are greatly sought after by the native fauna. A. glabra is an important wild species of Annonaceae due to the elevated pharmacological potential of its leaves and seeds. The species also has important agronomic uses, serving as grafting stock resistant to damp conditions in the cultivation of commercial varieties of the group.

In vitro cultivation has been recognized as the most adequate form of propagating this species in light of its high crossing rates (which results in the formation of very heterogeneous populations) and reduced rooting capacity (which makes conventional vegetative propagation difficult) (Scaloppi Júnior, 2003). Many attempts have been made to cultivate (Zobayed et al., 2002; Nagori \& Purohit, 2004) wild Annonaceae species (Santana et al., 2003; Oliveira et al., 2007, 2008; Santana et al., 2008a,b) through micropropagation, but low levels of explant multiplication, slow shoots growth rates, and elevated explant mortality during acclimatization have contributed to the limited commercial success of this technique.

Successful in vitro cultivation depends, to a very large degree, on a correct hormonal and mineral balance in the culture medium. Quantifying minerals levels in young

${ }^{1}$ Universidade Estadual de Feira de Santana/UEFS - Departamento de Ciências Biológicas - Avenida Transnordestina - s/n - $44036-900$ - Feira de Santana,BA - lenaldo@uefs.br

2Universidade Federal de Lavras/UFLA - Departamento de Biologia/DBI - Lavras, MG

${ }^{3}$ Universidade Estadual de Feira de Santana/UEFS - Departamento de Ciências Biológicas - Feira de Santana, BA 
plants and in the culture medium itself during explant growth would furnish important information for optimizing micropropagation protocols (Ramage \& Williams, 2002). As such, adequate hormonal control by way of the equilibrated addition of plant growth regulators combined with the elucidation of the interactions of these substances with the other components of the culture medium, could help overcome some of the obstacles related to the micropropagation of these plants.

Numerous studies have demonstrated that the mineral composition of the medium and the addition of different growth regulators affect explant development (Sato et al., 2001; Ramage \& Williams, 2002; Silva et al., 2003). Carvalho \& Biasi (2004) demonstrated that the amount of zeatin (ZEA) and indoleacetic acid (AIA) used to induce budding in explants of "caqui" (Diospyros kaki) can be reduced to $1 \mu \mathrm{M}$ and $0.01 \mu \mathrm{M}$, respectively, when these explants are cultivated in MS medium (Murashige \& Skoog, 1962) containing only half the normal concentration of $\mathrm{NO}_{3}$. It has also been suggested that the use of growth regulators (especially cytokinins) affects the rates of absorption and translocation of essential minerals in plants under in vitro conditions as they directly influence the formation and differentiation of the vascular system and the regulation of enzymes involved in the assimilatory metabolism of minerals, principally nitrogen (Aloni, 2001; Donato et al., 2003).

As such, the objective of the present work was to evaluate the effects of four different cytokinins on the uptake of essential minerals in shoots of A. glabra cultured in vitro, and examine their effects on plant growth and survival.

\section{MATERIALS AND METHODS}

Young plants of Annona glabra used to provide explants for the experiments described here were cloned in vitro from the same mother plant and maintained in a green house under photon irradiance of $130-170 \mathrm{~mol} . \mathrm{m}^{-2} . \mathrm{s}^{-1}$, a photoperiod of $16 \mathrm{hr}$, and without temperature control. Phytosanitary control of the plants included spraying with the fungicide Benlate $\left(2.0 \mathrm{~g} \mathrm{~L}^{-1}\right)$ one week before explant collection.

Nodule segments were removed from the stock plants and kept in running water in a laminar flow chamber for $6 \mathrm{hr}$, immersed in $70 \%$ ethyl alcohol (v/v) for 1 minute, and then sodium hypochlorite ( $1 \%$ active chloride) with a few drops of detergent during 15 minutes. The material was additionally washed in sterile distilled water, and subsequently isolated and maintained in a $200 \mathrm{mg} \mathrm{L}^{-1}$ solution of ascorbic acid for 5 minutes.
The nodule segments were inoculated into test tubes $(25 \times 150 \mathrm{~mm})$ containing $15 \mathrm{ml}$ of WPM medium (Lloyd \& Mccown, 1981) solidified with $0.65 \%$ agar and supplemented with $3 \mathrm{mg} \mathrm{L}^{-1}$ of sucrose and $1 \mathrm{mg} \mathrm{L}^{-1}$ of activated charcoal. The $\mathrm{pH}$ of the culture medium was adjusted to 5.7 before autoclaving. Treatments consisted of the addition of $1 \mathrm{mg} \mathrm{L}^{-1}$ concentrations of 6benzilaminopurine (BAP), thidiazuron (TDZ), kinetin (KIN) and zeatin (ZEA), in addition to controls without any cytokinin. The $1 \mathrm{mg} \mathrm{L}^{-1}$ cytokinin concentration used was based on the results obtained by Santana (2003) who reported inhibitory effects of some cytokinins on explant multiplication and rooting when used in concentrations above $2.0 \mathrm{mg} \mathrm{L}^{-1}$. Only ZEA was sterile filtered and added to the culture medium after autoclaving. After inoculation the test tubes were maintained in darkness for seven days and then transferred to an environment with a 16 hour photoperiod, a photon irradiance of $50 \mu \mathrm{mol} \mathrm{m} \mathrm{m}^{-2} \mathrm{~s}^{-1}$, and temperatures of $27 \pm 2^{\circ} \mathrm{C}$.

After 55 days of in vitro cultivation, evaluations of explant growth were made by quantifying the survival rate, number of buds per explant, bud length, as well as dry weight and leaf area, using five replicates per treatment, with each replicate composed of five tubes with one plant each. Buds were collected for mineral analysis at the same time and washed in distilled water, dried in a forced air oven at $60^{\circ} \mathrm{C}$ to $70^{\circ} \mathrm{C}$, weighed, and then ground to obtain the extracts.

Phosphorous $(\mathrm{P})$ content was determined using the molybdate colorimetric technique; potassium (K) by flame photometry; calcium $(\mathrm{Ca})$, magnesium $(\mathrm{Mg})$, copper $(\mathrm{Cu})$, iron $(\mathrm{Fe})$, manganese $(\mathrm{Mn})$, and zinc $(\mathrm{Zn})$ by atomic absorption spectrophotometry; sulfur (S) by turbidimetry with $\mathrm{BaCl}_{2}$; nitrogen $(\mathrm{N})$ by the semi micro Kjeldahl method; and boron (B) by colorimetry of curcumin/boric acid (Malavolta et al., 1997).

The experiment was conducted in a completely randomized design with three replicate per treatment, with each replicate composed of $5 \mathrm{mg}$ of fresh material. Statistical analyses were performed using the SISVAR 4.3 software program (Ferreira, 1999). Averages were compared by using the Scott-Knott test at a 5\% probability level.

\section{RESULTS AND DISCUSSION}

Significant effects $(\mathrm{P}<0.05)$ of cytokinin treatments on explants of Annona glabra were observed in relation to all of the variables analyzed. Treatment with kinetin (KIN) promoted the highest levels of explant survival, followed by treatment with 6-benzilaminopurine (BAP) (Table 1). 
Table 1 - Survival rate, number of shoot buds, leaf area, length, and dry weight of buds of Annona glabra cultivated in vitro in WPM medium supplemented with different cytokinins.

\begin{tabular}{cccccc}
\hline $\begin{array}{c}\text { Cytokinin } \\
\text { source }\end{array}$ & $\begin{array}{c}\text { Survival rate } \\
(\%)\end{array}$ & $\begin{array}{c}\text { Number of } \\
\text { buds }\end{array}$ & $\begin{array}{c}\text { Leaf area } \\
\left(\mathrm{cm}^{2}\right)\end{array}$ & $\begin{array}{c}\text { Bud length } \\
(\mathrm{cm})\end{array}$ & $\begin{array}{c}\text { Dry weight } \\
(\mathrm{mg})\end{array}$ \\
\hline Control & $68.50 \mathrm{c}$ & $0.59 \mathrm{c}$ & $4.55 \mathrm{~b}$ & $1.76 \mathrm{~b}$ & $82.60 \mathrm{~b}$ \\
BAP & $78.00 \mathrm{~b}$ & $1.33 \mathrm{~b}$ & $8.87 \mathrm{a}$ & $2.22 \mathrm{a}$ & $165.23 \mathrm{a}$ \\
KIN & $88.50 \mathrm{a}$ & $0.93 \mathrm{c}$ & $11.25 \mathrm{a}$ & $2.67 \mathrm{a}$ & $170.60 \mathrm{a}$ \\
TDZ & $73.00 \mathrm{c}$ & $1.26 \mathrm{~b}$ & $5.81 \mathrm{~b}$ & $1.15 \mathrm{c}$ & $111.41 \mathrm{~b}$ \\
ZEA & $66.50 \mathrm{c}$ & $2.93 \mathrm{a}$ & $6.85 \mathrm{~b}$ & $1.92 \mathrm{~b}$ & $82.65 \mathrm{~b}$ \\
\hline
\end{tabular}

*Averages followed by the same letters in any column indicate no significant differences between them, according to the ScottKnott test at a 5\% probability level.

Treatment with zeatin (ZEA) resulted in the largest number of buds per explant, followed by BAP and thidiazuron (TDZ). KIN and BAP provoked the largest increase in the bud length and leaf area, as well as the greatest dry weight accumulation (Table 1). Only the TDZ treatment resulted in growth reduction in buds of $A$. glabra in relation to the control group. Among the various treatments, the plants exposed to KIN appeared more vigorous, with thick, dark-green leaves. Vitrified plants were not seen in any of the samples.

Explants treated with KIN or BAP exhibited essentially the same responses among all of the variables analyzed - with the exception of survival rate, which was greater after KIN exposure (Table 1). Carvalho \& Biasi (2004) observed similar results with BAP and KIN in in vitro multiplication of "caqui". On the other hand, Fráguas et al. (2004) reported that the best growth of woody plants in vitro was obtained using BAP instead of KIN.

In spite of the fact that ZEA was the only cytokinin that induced multiple budding in A. glabra, few reports of the use of this growth regulator have been published possibly due to the high costs of this substance, which inhibits its wide use in commercial applications. However, ZEA has shown itself to be very efficient at eliciting budding in some species, such as kaki, (Diospyros kaki) (Carvalho \& Biasi, 2004), blueberry (Vaccinium ashei) (Silva et al., 2006), and Vaccinium vitis (Debnath \& Mcrae, 2002). Although TDZ is considered one of the most potent cytokinins, principally among woody plants, the reduced growth rate observed in buds of A. glabra at concentrations of $2 \mathrm{mg} \mathrm{L}^{-1}$ were very similar to the results obtained by Akasaka et al. (2000) - who noted a negative effect of this cytokinin on in vitro development of Arachis hypogaea.

Analyses of the mineral content of A. glabra buds indicated that concentrations of nitrogen, potassium, calcium, magnesium, boron, iron, and zinc were affected by the presence of cytokinins in the culture medium (Table 2).

It can be seen that all of the cytokinins resulted in increases in nitrogen levels, although the greatest increases resulted from the presence of KIN, BAP, and ZEA. Likewise, all of the cytokinins stimulated greater (and essentially equal) absorption of boron. On the other hand, all of the cytokinins tested provoked a reduction in calcium levels in the buds. Only ZEA stimulated greater accumulation of potassium and magnesium among the buds; while BAP induced a large uptake of iron (Table 2).

Barberaki \& Kintzios (2002) reported that the accumulation of macronutrients in plant tissue cultivated in vitro is greatly affected by the presence of growth regulators. These authors found that cytokinins principally influence the accumulation of nitrogen, phosphorous, calcium, and magnesium in callus tissue of Viscum album.

Nitrogen is essential for normal growth and development in plants, and plays an important role in regulating of many physiological functions (Konno et al., 1999; Ramage \& Williams, 2002). Leljak-Levanic et al. (2004) demonstrated that $\mathrm{NH}_{4}{ }^{+}$and $\mathrm{NO}_{3}{ }^{-}$concentrations in the culture medium affect numerous morphogenetic responses, including the development of callus tissue and somatic embryos. Sivakumar et al. (2005) reported that a correct balance between $\mathrm{NH}_{4}^{+}$and $\mathrm{NO}_{3}^{-}$in the culture medium is directly related to biomass accumulation in chrysanthemums. In the present work, explants cultivated in the presence of BAP and KIN demonstrated a greater accumulation of nitrogen in the buds, as well as greater growth, leaf thickness, shoots length, and dry weight (Table 1). This suggests a possible link between cytokinins and the enzymes involved in the nitrogen assimilation (Samuelson et al., 1995). Similarly, Chauhan \& Kothari (2004) found that 6-benzilaminopurine acts synergistically with $\mathrm{AgNO}_{3}$ in stimulating bud regeneration in leaf explants of Hordeum vulgare. 
Table 2 - Macro-element content: nitrogen $(\mathrm{N})$, phosphorous $(\mathrm{P})$, potassium $(\mathrm{K})$, calcium $(\mathrm{Ca})$, magnesium $(\mathrm{Mg})$, and sulfur $(\mathrm{S})$; and micro-element content: boron $(\mathrm{B})$, copper $(\mathrm{Cu})$, iron $(\mathrm{Fe})$, manganese $(\mathrm{Mn})$, and zinc $(\mathrm{Zn})$ of Annona glabra cultivated in vitro in WPM medium supplemented with different cytokinins.

\begin{tabular}{|c|c|c|c|c|c|c|}
\hline \multirow{2}{*}{ Cytokinin source } & \multicolumn{6}{|c|}{ Macro-elements $\left(\mathrm{g} \mathrm{kg}^{-1}\right)$} \\
\hline & $\mathrm{N}$ & $\mathrm{P}$ & $\mathrm{K}$ & $\mathrm{Ca}$ & $\mathrm{Mg}$ & $\mathrm{S}$ \\
\hline Control & $25.26 \mathrm{c}$ & $0.737 \mathrm{a}$ & $19.39 \mathrm{~b}$ & $6.61 \mathrm{a}$ & $2.11 \mathrm{~b}$ & $7.91 \mathrm{a}$ \\
\hline BAP & $50.80 \mathrm{a}$ & $0.608 \mathrm{a}$ & $19.09 \mathrm{~b}$ & $4.86 \mathrm{~b}$ & $2.18 \mathrm{~b}$ & $8.77 \mathrm{a}$ \\
\hline KIN & $51.66 \mathrm{a}$ & $0.670 \mathrm{a}$ & $20.13 \mathrm{~b}$ & $4.67 \mathrm{~b}$ & $2.04 \mathrm{~b}$ & $7.95 \mathrm{a}$ \\
\hline TDZ & $47.13 \mathrm{~b}$ & $0.656 \mathrm{a}$ & $20.30 \mathrm{~b}$ & $5.37 \mathrm{~b}$ & $2.05 \mathrm{~b}$ & $8.61 \mathrm{a}$ \\
\hline ZEA & $50.37 \mathrm{a}$ & $0.674 \mathrm{a}$ & $22.27 \mathrm{a}$ & $5.00 \mathrm{~b}$ & $3.16 \mathrm{a}$ & $8.05 \mathrm{a}$ \\
\hline \multirow{2}{*}{ Cytokinin source } & \multicolumn{6}{|c|}{ Micro-elements $\left(\mathrm{mg} \mathrm{kg}^{-1}\right)$} \\
\hline & $\mathrm{B}$ & $\mathrm{Cu}$ & & & $\mathrm{Mn}$ & $\mathrm{Zn}$ \\
\hline Control & $76.00 \mathrm{~b}$ & $11.66 \mathrm{a}$ & & & $273.00 \mathrm{a}$ & $110.33 \mathrm{~b}$ \\
\hline BAP & $91.00 \mathrm{a}$ & $10.66 \mathrm{a}$ & & & $249.66 \mathrm{a}$ & $131.33 \mathrm{a}$ \\
\hline KIN & $100.00 \mathrm{a}$ & $10.33 \mathrm{a}$ & & & $255.00 \mathrm{a}$ & $126.00 \mathrm{a}$ \\
\hline TDZ & $95.66 \mathrm{a}$ & $12.33 \mathrm{a}$ & & & $225.33 \mathrm{a}$ & $112.33 \mathrm{~b}$ \\
\hline ZEA & $96.66 \mathrm{a}$ & $9.33 \mathrm{a}$ & & a & $245.33 \mathrm{a}$ & 129.00 \\
\hline
\end{tabular}

* Averages followed by the same letters in any column indicate no significant differences between them, according to the ScottKnott test at a 5\% probability level.

Even though cytokinins were not observed to have any effect on the accumulation of phosphorous in the present work, we did observed that its levels were considerably lower in the explants than the average values for most plant cultures (Malavolta et al., 1997). Diniz et al. (1999) pointed out that low levels of phosphorous in in vitro culture media may be responsible for the low growth rates observed in some species. This author considered the interaction of phosphorous with other medium salts (the latter often in excess in the medium) to be responsible for the small amounts of phosphorous present in plants maintained in this type of environment. Another relevant fact is the reduction of the media $\mathrm{pH}$ during in vitro cultivation, which reduces phosphorous solubility, and therefore its availability for uptake.

An important result in the present research was the marked reduction in calcium concentration in explants exposed to cytokinins (Table 2). Calcium is directly involved in the processes of cell division in the meristematic zones of plants, affecting their viability and bud formation and, consequently, the plant's multiplication rate. Calcium also participates in the synthesis of pectin molecules involved in cell wall formation (Konno et al., 1999), and the lack of this element may alter the structure and metabolism of the pectin molecules, reducing the mitotic index in these plants. Additionally, reduction of the calcium content in tissues cultivated in vitro is directly related to physiological disorders such as necrosis of the apex and vitrification.
Another interesting point was the observed strongly positive effects of the cytokinins on boron absorption observed in the present work (Table 2). Boron is the micronutrient that most restricts plant production, and symptoms of its deficiency and of the toxicity of this nutrient are limited by its extremely low mobility (Malavolta et al., 1997). Boron deficiency affects cell wall formation, cell division and cell size. Salvador et al. (2003) observed a positive correlation between the leaf content of boron and phosphorous absorption, and attributed this interaction to boron's role in phosphorous transport through the cell membrane. In the present work, however, the high level of boron concentrations in plants treated with cytokinins did not appear to affect phosphorous uptake.

The present work indicated that iron absorption was increased by addition of BAP and ZEA to the culture medium. The presence of iron has been related to the degree of oxidation of explants maintained in in vitro conditions, and this element is an important constituent of the enzymes liberated as a result of cell damage, and which initiate a series of oxidative response processes. The observed increase in the iron content is interesting as woody species generally demonstrate high levels of tissue oxidation during in vitro establishment - which represents one of the limiting factors in using this technique with this group of plants, especially the Annonaceae (Santana et al., 2003; Oliveira et al., 2007). 
Our results indicate the necessity of developing new formulations for the essential minerals used in in vitro culture media, taking into consideration the presence of growth regulators and the mineral composition of the cultivated tissues themselves. Staikidou et al. (2006), for example, improved in vitro growth of species of Galanthus by developing a culture medium based on the mineral composition of the bulbs of this plant.

As the presence of cytokinins affects the absorption of various elements, the morphogenetic effects resulting from interactions between different minerals must also be considered in choosing a growth medium. In a recent study of the interactive effects of essential elements on in vitro plant tissue growth conducted by Randall \& Terrence (2007), these authors elaborated and confirmed algorithms for growth regulation in non-embryonic callus tissue from oranges (valencia variety). These authors subdivided the mineral components of the MS medium into five distinct groups, and determined that a greater availability of $\mathrm{NH}_{4} \mathrm{NO}_{3}$ and $\mathrm{Fe}^{++}$in the culture medium was essential for callus growth in this species - with a rapid decrease in fresh weight being observed as a result of the progressive reduction of $\mathrm{Fe}^{++}$and $\mathrm{NH}_{4} \mathrm{NO}_{3}$ levels.

\section{CONCLUSIONS}

The evaluation of the effect of different sources of cytokinins on shoots obtained from cloned plants of Annona glabra demonstrated that the presence of 6benzilaminopurine (BAP), thidiazuron (TDZ), kinetin (KIN), and zeatin (ZEA) increased nitrogen and boron absorption and assimilation and reduced calcium concentrations in buds of A. glabra during in vitro culture. It also shows that KIN and BAP stimulated the growth of explants of $A$. glabra in in vitro culture.

\section{ACKNOWLEDGEMENTS}

The authors would like to thank the Fundação de Amparo a Pesquisa do Estado de Minas Gerais (FAPEMIG) for financial support of this work.

\section{REFERENCES}

AKASAKA, Y.; DAIMON, H.; MII, M. Improved plant regeneration from cultured leaf segments in peanut (Arachis hypogaea L.) by limited exposure to thidiazuron. Plant Science, Clare, v.156, p.169-175, 2000.

ALONI, R. Foliar and axial aspects of vascular differentiation: hypotheses and evidence. Journal Plant Growth Regulation, New York, v.20, n.1, p.22-34, 2001.
BARBERAKI, M.; KINTZIOS, S. Accumulation of selected macronutrients in mistletoe tissue cultures: effect of medium composition and explant source. Scientia Horticulturae, Amsterdam, v.95, n.12, p.133150, 2002.

CARVALHO, D.C.; BIASI, L.A. Organogênese do caquizeiro a partir de segmentos radiculares. Ciência Rural, Porto Alegre, v.34, n.5, p.401-1406, 2004.

CHAUHAN, M.; KOTHARI, S.L. Optimization of nutrient levels in the medium increases the efficiency of callus induction and plant regeneration in recalcitrant Indian barley (Hordeum vulgare L.). In vitro Cellular \& Development Biology Plant, Gaithersburg, v.40, p.520 527,2004

DEBNATH, S.C.; MCRAE, K.B. An efficient adventitious shoot regeneration system on excised leaves of micropropagated lingonberry (Vaccinium vitis-ideaea L.). Journal of Horticultural Science and Biotecnology, Ashford, v.77, n.6, p.744-752, 2002.

DINIZ, J.D.N.; GONÇALVES, N.A.; HERNANDEZ, F.F.F.; TORRES, A.C. Absorção de macronutrientes por explantes de bananeira in vitro. Pesquisa

Agropecuária Brasileira, Brasília, v.34, n.7, p.12011209, 1999.

DONATO, V.M.T.S.; ANDRADE, A.G.; SOUZA, E.S.; FRANÇA, J.G.E. Metabolismo de plantas de cana-deaçúcar cultivadas in vitro sob diferentes concentrações de nitrogênio. Pesquisa Agropecuária Brasileira, Brasília, v.38, n.12, p.1373-1379, 2003.

\section{FERREIRA, D.F. SISVAR 4.3 - Sistema de análises} estatísticas. Lavras: UFLA, 1999.

FRÁGUAS, C.B.; PASQUAL, M.; PEREIRA, A.R. Multiplicação in vitro de Ficus carica L.: efeito da cinetina e do ácido giberélico. Ciência e Agrotecnologia, Lavras, v.28, n.1, p.49-55, 2004.

KONNO, H.; NAKASHIMA, S.; MAITANI, T.; KATOH, $\mathrm{K}$. Alteration of pectic polysaccharides in cell walls, extracellular polysaccharides and glycan-hydrolytic enzymes of growth-restricted carrot cells under calcium deficiency. Physiologia Plantarum, Copenhagen, v.107, n.3, p.287-293, 1999 
LELJAK-LEVANIC, D.; BAUER, N.; MIHALJEVIC, S.; JELASKA, S. Somatic embryogenesis in pumpkin (Cucurbita pepo L.): control of somatic embryo development by nitrogen compounds. Journal of Plant Physiology, Leipzig, v.161, p.229-236, 2004.

LLOYD, G.; MCCOWN, B. Use of microculture for production and improvement of Rhododendron spp. HortScience, Alexandria, v.15, p.416-418, 1981.

MALAVOLTA, E.; VITTI, G.C.; OLIVEIRA, S.A. Avaliação do estado nutricional das planta: princípios e aplicações. Piracicaba: POTAFOS, 1997. 319p.

MURASHIGE, T.; SKOOG, F.A. A revised medium for rapid growth and biomassis with tabaco tissue cultures.

Physiologia Plantarum, Copenhagen, v.15, p.473-492, 1962.

NAGORI, R.; PUROHIT, S.D. In vitro planted regeneration in Annona squamosa L. through direct shoot bud differentiation on hypocotyls segments. Scientia Horticulturae, Amsterdam, v.99, n.1, p.89-98, 2004.

OLIVEIRA, L.M.; PAIVA, R.; SANTANA, J.R.F.; ALVES, E.; NOGUEIRA, R.C.; PEREIRA, F.D. Effect of cytokinins on in vitro development of autotrophism and acclimatization of Annona glabra L. In vitro Cellular \& Development Biology Plant, Gaithersburg, v.44, p.128135, 2008.

OLIVEIRA, L.M.; PAIVA, R.; SANTANA, J.R.F.; NOGUEIRA, R.C.; SOARES, F.P.; SILVA, L.C. Efeito de citocininas na senescência e abscisão foliar durante o cultivo in vitro de Annona glabra L. Revista Brasileira de Fruticultura, Jaboticabal, v.29, n.1, p.25-30, 2007.

RAMAGE, C.M.; WILLIAMS, R.R. Mineral nutrition and plant morphogensis. In vitro Cellular \& Development Biology, Gaithersburg, v.38, p.115-124, 2002.

RANDALL, P.N.; TERRENCE, J.E. Regulating plant tissue growth by mineral nutrition. In vitro Cellular \& Development Biology, Gaithersburg, v.43, p.370-381, 2007.

SALVADOR, J.O.; MOREIRA, A.; MALAVOLTA, E.; CABRAL, C.P. Influência do boro e do manganês no crescimento e na composição mineral de mudas de goiabeira. Ciência e Agrotecnologia, Lavras, v.27, n.2, p.325-331, 2003.
SAMUELSON, M.E.; CAMPBELL, W.H.; LARSSON, C.M. The influence of cytokinins in nitrate regulation of nitrate reductase activity and expression in barley. Physiologia Plantarum, Copenhagen, v.93, n.3, p.533539, 1995.

SANTANA, J.R.F.; PAIVA, R.; ALOUFA, M.A.I.; LEMOS, E.E.P. Efficiency of amplicillin and benomyl at controlling contamination of Annonaceae leaf segments cultured in vitro. Fruits, Paris, v.58, n.4, p.357-361, 2003.

SANTANA, J.R. F.; PAIVA, R.; PEREIRA, F.D.; OLIVEIRA, L.M. Estímulo do comportamento fotoautotrófico durante o enraizamento in vitro de Annona glabra L.: I., desenvolvimento do sistema radicular e da parte aérea. Ciência e Agrotecnologia, Lavras, v.32, n.1, p.80-86, 2008a.

SANTANA, J.R.F.; PAIVA, R.; REZENDE, R.K.S.; CASTRO, E.M.; PEREIRA, F.D.; OLIVEIRA, L.M. Estímulo do comportamento fotoautotrófico durante o enraizamento in vitro de Annona glabra L.: II., aspectos da anatomia da folha antes da aclimatização. Ciência e Agrotecnologia, Lavras, v.32, n.2, p.640-644, 2008 b.

SATO, A.Y.; PINTO, J.E.B.P.; MORAIS, A.R.; LAMEIRA, A.O. Efeito de diferentes níveis de nitrogênio, em presença ou ausência de benzilaminopurina, na multiplicação de gérbera (gerbera sp.) de vaso. Ciência e Agrotecnologia, Lavras, v.25, n.5, p.1071-1078, 2001.

SCALOPPI JUNIOR, E.J. Clonagem de quatro espécies de Annonaceae potenciais como porta-enxertos. Revista Brasileira de Fruticultura, Jaboticabal, v.25, n.2, p.286289, 2003.

SILVA, F.G.; PINTO, J.E.B.P.; SALES, J.F.; DIVINO, S.P.; BERTOLUCCI, S.K.V. Efeito da concentração de sais e fitorreguladores na indução de calos em carqueja. Ciência e Agrotecnologia, Lavras, v.27, n.3, p.541-547, 2003.

SILVA, L.C.; SCHUCH, M.W.; SOUZA, J.A.; ERIG, A.C.; ANTUNES, L.E.C. Meio nutritivo, reguladores de crescimento e frio no estabelecimento in vitro de mirtilo (Vaccinium ashei Reade) cv. Delite. Revista Brasileira de Agrociência, Pelotas, v.12, n.4, p.405408, 2006. 
SIVAKUMAR, G.; KIM, S.J.; HAHN, E.J.; PAEK, K.Y. Optimizing environmental factors for large-scale multiplication of Chrysanthemum (Chrysanthemum grandiflorum) in balloon-type bioreactor culture. In vitro Cellular \& Development Biology, Gaithersburg, v.41, p.822-825, 2005.

STAIKIDOU, I.; SELBY, C.; HANKS, G.R. Development of a medium for in vitro culture of Galanthus species based on the mineral composition of bulbs. Journal of Horticulture Science Biotechnology, Ahsford, v.81, p.537-545, 2006.

ZOBAYED, S.M.A.; ARMSTRONG, J.; ARMSTRONG, W. Multiple shoot induction and leaf and flower bud abscission of Annona cultures as affected by types of ventilation. Plant Cell, Tissue and Organ Culture, Dordrechet, v.69, n.2, p.155-165, 2002. 